\title{
The U.S. ESRDC Advances Power System Research for Shipboard Systems
}

\author{
Noel N. Schulz ${ }^{1}$, Robert E. Hebner ${ }^{2}$, Steinar Dale ${ }^{3}$, Roger Dougal ${ }^{4}$, Scott Sudhoff ${ }^{5}$, Ed Zivi ${ }^{6}$, Chryssostomos \\ Chryssostomidis ${ }^{7}$ \\ ${ }^{1}$ Mississippi State University, USA/Cardiff University, Wales, UK, Schulz@ece.msstate.edu \\ ${ }^{2}$ University of Texas-Austin, USA ${ }^{3}$ Florida State University, USA ${ }^{4}$ University of South Carolina, USA \\ ${ }^{5}$ Purdue University, USA ${ }^{6}$ U.S. Naval Academy, USA ${ }^{7}$ MIT, USA
}

\begin{abstract}
In an effort to advance the research and development capabilities related to shipboard power systems, the U.S. Office of Naval Research created the Electric Ship Research and Development Consortium. This group of seven U.S. universities is working to develop near term and far term research solutions for ship power systems on the all-electric ship. This paper provides an overview of the ESRDC, its successes, resources, and activities related to education and research efforts.
\end{abstract}

\section{INTRODUCTION}

In the late 1990s, the U.S. Navy began pursuing additional research and development activities related to the all electric ship. Traditionally U.S. ships have had mechanical propulsion and the electric generation and loads on the ship were small to meet the requirements of the hotel functionality of the ship. However, the option of electric propulsion provided new opportunities for using electrical energy on the ship. With the additional electrical energy available when it was not being used for propulsion, new weapons, radars and launch systems could be considered for installation on the ship. Additionally with the goals of additional automation of ship functionality and reducing personnel on the ships, the effective integration of monitoring, control and operational systems to help with ship reconfiguration, survivability and fight through capabilities became even more critical to the design and development of the next generation ship.

In addition to the changes related to electric power systems on the ships, the ship building community began to see a paradigm shift. In the past the electrical engineering component of the shipbuilding community had been a minor, secondary part of the process. In many cases the shipbuilders were given a set of plans and asked to implement these plans and build the ship shown in the designs. Today, the U.S. Navy has changed its strategy and the shipbuilding community is more involved in the design of sub-systems and interconnected systems on the ship. With the expectation of additional electric power capabilities on the ship, the expertise of power engineering is becoming more critical to the workforce of the ship builders and system integrators.

These two challenges helped provide the momentum for the development of the U.S. Office of Naval Research (ONR) Electric Ship Research and Development Consortium (ESRDC) [1] in 2002. The U.S. ONR decided to create a consortium of universities to focus on the research and development activities related to the all electric ship. By creating the consortium, ONR hoped to leverage the individual research projects at the universities into a combined team approach where faculty and students at multiple universities could collaborate and interact on problems to develop innovative solutions. The ESRDC was initially funded for five years. Recently ONR approved the renewal of the ESRDC funding for 2007-2012.

The ESRDC members are the Florida State University, Massachusetts Institute of Technology, Mississippi State University, Purdue University, U.S. Naval Academy, the University of South Carolina and the University of TexasAustin. This paper will outline some of the achievements of the ESRDC over the last five years related to research and development as well as workforce issues.

\section{BACKGROUND}

As the Navy was anticipating the transition to electric ships, it recognized that much of the leading expertise in the area was in Europe and Asia and not in the U.S. To correct this situation, a three part investment strategy was adopted:

- A large investment in industrial development so the U.S. would have key onshore suppliers of near term technology

- A large investment in the Navy to have Navy people and organizations to lead the transition

- A much smaller, but important, investment in universities to provide world leadership in the technology and a source of educated employees for the Navy and industry.

The Office of Naval Research conducted a bold experiment with respect to the university investment. In addition to maintaining a healthy set of single investigator projects, it also established a consortium to stimulate a multidisciplinary approach to a multidisciplinary challenge.

Early in 2001, the Office of Naval Research brought together faculty and administrators from four universities to discuss plans for a university consortium. Florida State University was the lead university and the other three universities were Mississippi State University, University of South Carolina and University of Texas at Austin. The initial research efforts started during the summer of 2002. During the summer of 2004, ONR and the leadership of the consortium decided to add three additional universities, M.I.T., Purdue University and the U.S. Naval Academy.

The ESRDC has a Board of Directors that provides leadership for the group. Each university has a representative 
on the Board. The Board meets monthly, by either phone or in person, to discuss research activities, update ONR and investigate opportunities for future collaborations.

\section{ACTIVITIES OF THE ESRDC}

\section{A. Technical Success}

The consortium has been a technical success. Important accomplishments include:

- Modeling and simulation capability that has been used by industry and the Navy in the design of new equipment and systems.

- Prototype development and testing capability that have contributed to the Navy's decision to fund at least three major development programs with industry.

- Technology and software that is being adopted by industry for integration into the fleet.

- Workshops on modeling and simulation, reconfiguration, and power train technology that brought leaders of industry, government and academe to discuss and stimulate technical advances in this area.

- More than 300 papers were presented to the technical community helping to establish U.S. leadership in this area.

- More than 50 students have received advanced degrees for research conducted in support of future electric ships

\section{B. Consortium Technical Thrusts}

For the 2007-2012 renewal period the ESRDC has five major thrusts. Those are:

- Computational tools for early-stage ship design

- Ship electric power system

- Total ship system solution to thermal management

- Load management

- $\quad$ Next Generation Integrated Power System (NGIPS)

As part of the consortium's activities, in addition to these areas, the ESRDC works with ONR, NAVSEA (Naval Sea Systems Command), Naval Surface Warfare Center (NSWC)Carderock Division and NSWC Philadelphia on pressing issues related to future ship system activities. In the summer and fall of 2007, the ESRDC team pulled together a group of researchers to look at energy storage issues. For 2008 and 2009, the ESRDC team will be investigating models and simulation activities related to a medium voltage DC (MVDC) distribution system. The work on the MVDC system includes a full system simulation and a demo with other navy resources.

\section{Educational Efforts}

In addition to our research efforts, one of the other benefits of the ESRDC is the development of a future workforce that has the skill set necessary to tackle the challenges of designing and building the next generation electric ship. The involvement of the U.S. Naval Academy (USNA) provides a direct conduit between the research activities of the ESRDC and USNA Midshipmen. Additionally several of the USNA students have continued their studies through research activities at Purdue University.

MIT houses the Naval Construction and Engineering Program which trains active-duty U.S. Navy and U.S. Coast Guard officers. Participants earn graduate degrees in naval engineering and ship design through a curriculum sponsored by Naval Sea Systems Command. Besides providing the officers with a comprehensive education in naval engineering, it emphasizes their future roles as advocates for innovation in ship design and acquisition.

MSU has piloted a program where current shipyard employees are given fellowships to participate in distance education graduate classes. To date over 10 engineers from one shipbuilder have taken graduate classes and over half of them are also pursuing graduate degrees.

All the universities have had the opportunity for faculty to integrate their research activities into their graduate and undergraduate classes. A recent paper by faculty at MSU highlighted some of these opportunities [2]. As mentioned above, the ESRDC has awarded over 50 advanced engineering degrees for students who have done research in the area of shipboard power systems.

\section{Dissemination within the Consortium and Beyond}

In addition to the collaborative projects, it is important for researchers to share their research findings with other researchers both within the consortium and in the general research community. Each year one of the universities hosts a two day conference for the ESRDC faculty, staff and students. At this conference presentations and posters provide a platform for over 100 researchers to discuss past research and future collaborations. Information on past workshops is available at http://esrdc.com/previous.workshops.html

In May of 2008, the consortium combined its annual meeting with a one and a half day meeting with industry. The meeting was co-sponsored by ONR 334 and included government entities, shipbuilders and other industrial representatives.

Besides the annual conferences, the ESRDC has also planned and organized three workshops for dissemination to the ship community. These workshops were:

- Workshop on Transportable Megawatt Power Systems, March 2007, University of Texas, Austin, Texas

- ESRDC Controls Workshop, August 2006, Purdue University, West Lafayette, Indiana

- Workshop on simulation based design for electric war ships, February 2006, Florida State University, Tallahassee, Florida

Consortium members have also been very active on planning committees related to national and international electric ship conferences. Consortium researchers has helped organize ASNE (American Society for Naval Engineers http://www.navalengineers.org/) meetings and the IEEE Electric Ship Technologies Symposia (http://ewh.ieee.org/conf/ests07/). 


\section{E. Unique Research Facilities}

The Electric Ship Research and Development Consortium is powered by some of the most sophisticated and state-of-theart research facilities in the world. Together, team members offer research and laboratory settings that maximize each other's strengths and provide a truly unique setting to achieve great success. The following provides a brief overview of several of the consortium's unique research facilities.

The FSU Center for Advanced Power Systems (CAPS) has power systems research capabilities that consist of an advanced prototype test facility for testing and analysis of power systems and electric machinery and components up to $5 \mathrm{MW}$ and real-time digital modeling and simulation capability for power systems research and hardware in the loop experimentation. The Advanced Prototype Test Facilities allows for testing electric machines, components and systems at up to $5 \mathrm{MW}$. In addition to a variety of PC based modeling and simulation tools such as MATLAB/ Simulink and PSCAD/EMTDC, the CAPS facility features a specialized high-performance Real Time Digital Simulator (RTDS) designed particularly for real-time solution of complex power systems models. This system has been gradually expanded to include fourteen "racks" consisting of a large number of parallel processors (typically 26-30 each). The entire system is capable of simulating in real-time approximately 500 electrical nodes and 5,000 control components.

Purdue University maintains extensive laboratory facilities for the study of electric machinery, power electronics, and power electronics-based distribution and propulsion systems. Purdue's Genetic Optimization Processing Array (GOPA) consists of 216 high-end processors operated in parallel and used to obtain solutions of genetic optimization problems. In particular, it is suited for solving problems related to parameter identification and component/system design. The facility is currently being used for the design of energy conversion components such as electric machinery and power electronics converters.

The Naval Combat Survivability Test bed (NCST) at Purdue was developed through the support of Naval Sea Systems Command and ONR for the purpose of validating new approaches to design, control, modeling and simulation of the next generation of naval power distribution and propulsion systems. The NCST is a scaled version of a future naval power distribution and propulsion concept.

The University of Texas at Austin, in its Center for Electromechanics, has extensive in-house fabrication, assembly and testing facilities. The facility also houses a high-energy spin test bunker designed to safely contain a 20 psig internal overpressure. The 600-square-foot spin test bunker features 30-inch-thick fiberglass-reinforced concrete walls with 6-inch-thick aluminum door, window and roof closures. These facilities are essential for flywheel research.

A 75-foot-deep vertical gun range is located between the north end of the main high bay and the spin test bunker. The seven-story vertical range is serviced by a three-person elevator and currently houses a $90 \mathrm{~mm}$ bore by 10 -meter long railgun and bore honing system.
The Power and Energy Systems research group at the University of South Carolina occupies three labs on campus including the Real-time Electromechanics Laboratory, the Power Electronics Laboratory, and the Power Sources Laboratory. The work in the Power Sources Laboratory addresses issues related to power sources, especially fuel cell power sources and hybrid configurations of those sources that include integral energy storage systems and power management systems. The laboratory contains a PEM fuel cell, advanced batteries and supercapacitors, and power supplies operating at up to $\mathrm{kW}$ levels. The laboratory also houses a modular linear permanent magnet motor of $3 \mathrm{~m}$ length.

One of the key contributions from USC has been the long term development of VTB (Virtual Test Bed) [3]. VTB is a software for prototyping of large-scale, multi-technical dynamic systems. The application driving development of the VTB is advanced power systems for navy platforms. The Virtual Test Bed strives to fill this need by providing an environment where each team member can fully participate in construction of the interdisciplinary virtual prototype while using their existing intellectual property (component models) and existing modeling skills (preferred languages and environments).

Mississippi State University resource contributions to the ESRDC projects are a combination of software and hardware capabilities to allow continuing research activities as well as branching into new areas. Two unique facility contributions are the Power Electronics Research Laboratory and the High Voltage Laboratory. The Power Electronics Research Laboratory is designed to use power electronic devices for the conversion and utilization of electric energy. This lab includes multiple Power Electronic Building Blocks (PEBB) devices in a hardware test bed. The MSU High Voltage Laboratory is the largest university high voltage laboratory in North America [4]. The High Voltage Laboratory has the following hardware equipment:

- 3000 kV, 56 kJ Impulse Generator

- $1000 \mathrm{kV}, 60 \mathrm{~Hz}, 1000 \mathrm{kVA}$ Conventional Test Transformer with Regulator and Measurement System

- $40 \mathrm{kV}, 60 \mathrm{~Hz}, 10 \mathrm{kVA}$ Conventional Test Transformer with Regulator and Measurement System

- Dielectric Test System, Pulse Frequency from $200 \mathrm{~Hz}$ to $40 \mathrm{kHz},+/-1600 \mathrm{~V}$

- Digital measurement and analysis tools

MSU has special software allowing for three-dimensional analysis and characterization of partial discharge in cables and insulation of motors. Additionally, commercial software to analyze the statistics of breakdown and the aging phenomena in dielectric materials is available.

Researchers at MIT have access to a numerous facilities and laboratories at MIT such as the Propeller Tunnel and the Design Laboratory. The Design Laboratory of the MIT Center for Ocean Engineering was founded in 1972 by Professor Chryssostomidis to research ship design and marine topics using CAD (Computer Aided Design) methods. The lab's research is in ship design, offshore structure design, marine robotics, geometric modeling, solid modeling, 
advanced manufacturing (solid free-form fabrication), distributed systems, computational geometry, ship building, producibility, and life-cycle issues.

The Marine Hydrodynamics Laboratory is home to a recirculating, variable pressure water tunnel. Originally developed for the testing of ship propellers, the water tunnel employs a moving stream of water rather than a moving object as in a towing tank. State-of-the-art flow visualization and measurement devices are used at this facility, including Particle Image Velocimetry and Laser Doppler Velocimetry. Recent work includes drag reduction tests with electromagneto-hydrodynamics, turbulence reduction through fishlike swimming motions, snake-swimming and flapping foil experiments.

\section{SUMMARY}

This paper has provided an overview of an academic research consortium between seven U.S. universities and the U.S. Office of Naval Research that has provided synergy in the area of shipboard power system research for the last six years. It outlines the ESRDC's technical successes, research thrusts, educational activities, dissemination efforts and unique facilities that provide a foundation for essential research activities for the next generation all-electric ship technologies. The ESRDC has developed into a key resource for the U.S. naval community related to partnering to solve near term and far term research and development activities related to shipboard power systems. Detailed information about specific research efforts is available from the authors.

\section{ACKNOWLEDGMENTS}

The authors acknowledge the support of the U.S. Office of Naval Research through ONR grants No. N00014-02-1-0623 and N00014-08-1-0080. Additionally we acknowledge the contributions of Mr. Terry Ericsen for his continued efforts to challenge the ESRDC members to push state-of-the-art to help solve future challenges for shipboard power systems.

\section{REFERENCES}

[1] Electric Ship Research and Development Consortium Website, http://www.esrdc.com/

[2] N. Schulz, S. Grzybowski, H.Ginn, A. Srivastava and J. Bastos, "Integrating Shipboard Power System Topics into the Curriculum," Proceedings of the 2007 Annual American Society for Engineering Education Conference, June, 2007, Honolulu, Hawaii.

[3] Virtual Test Bed, Department of Electrical and Computer Engineering, University of South Carolina, Columbia, SC, http://vtb.engr.sc.edu/

[4] High Voltage Laboratory, Department of Electrical and Computer Engineering, Mississippi State University, Starkville, MS, http://www.ece.msstate.edu/research/hvl/ 